\title{
Interrelationships Between Vent Fluid Chemistry, Temperature, Seismic Activity, and Biological Community Structure at a Mussel-Dominated, Deep-Sea Hydrothermal Vent Along the East Pacific Rise
}

\author{
Author(s): Richard A. Lutz, Timothy M. Shank, George W. Luther III , Costantino Vetriani , Maya \\ Tolstoy, Donald B. Nuzzio, Tommy S. Moore, Felix Waldhauser, Melitza Crespo-Medina, Aspassia D. \\ Chatziefthimiou , Eric R. Annis , and Andrew J. Reed \\ Source: Journal of Shellfish Research, 27(1):177-190. 2008. \\ Published By: National Shellfisheries Association \\ DOI: http://dx.doi.org/10.2983/0730-8000(2008)27[177:IBVFCT]2.0.CO;2 \\ URL: http://www.bioone.org/doi/full/10.2983/0730-8000\%282008\%2927\%5B177\%3AIBVFCT \\ $\% 5 \mathrm{D} 2.0 . \mathrm{CO} \% 3 \mathrm{~B} 2$
}

BioOne (www.bioone.org) is a nonprofit, online aggregation of core research in the biological, ecological, and environmental sciences. BioOne provides a sustainable online platform for over 170 journals and books published by nonprofit societies, associations, museums, institutions, and presses.

Your use of this PDF, the BioOne Web site, and all posted and associated content indicates your acceptance of BioOne's Terms of Use, available at www.bioone.org/page/terms_of_use.

Usage of BioOne content is strictly limited to personal, educational, and non-commercial use. Commercial inquiries or rights and permissions requests should be directed to the individual publisher as copyright holder. 


\title{
INTERRELATIONSHIPS BETWEEN VENT FLUID CHEMISTRY, TEMPERATURE, SEISMIC ACTIVITY, AND BIOLOGICAL COMMUNITY STRUCTURE AT A MUSSEL-DOMINATED, DEEP-SEA HYDROTHERMAL VENT ALONG THE EAST PACIFIC RISE
}

\author{
RICHARD A. LUTZ, ${ }^{1 *}$ TIMOTHY M. SHANK, ${ }^{2}$ GEORGE W. LUTHER III, ${ }^{3}$ \\ COSTANTINO VETRIANI, ${ }^{1,4}$ MAYA TOLSTOY, ${ }^{5}$ DONALD B. NUZZIO, ${ }^{6}$ \\ TOMMY S. MOORE, ${ }^{3}$ FELIX WALDHAUSER, ${ }^{5}$ MELITZA CRESPO-MEDINA,, 4 \\ ASPASSIA D. CHATZIEFTHIMIOU, ${ }^{1,4}$ ERIC R. ANNIS ${ }^{1}$ AND ANDREW J. REED ${ }^{1}$ \\ ${ }^{1}$ Institute of Marine and Coastal Sciences, Rutgers University, New Brunswick, New Jersey 08901; \\ ${ }^{2}$ Biology Department, Woods Hole Oceanographic Institution, Woods Hole, Massachusetts 02543; \\ ${ }^{3}$ College of Marine Studies, University of Delaware, Lewes, Delaware 19958; ${ }^{4}$ Department of \\ Biochemistry and Microbiology, Rutgers University, New Brunswick, New Jersey 08901 \\ ${ }^{5}$ Lamont-Doherty Earth Observatory, Palisades, New York 10964; ${ }^{6}$ Analytical Instrument Systems, \\ Inc., P.O. Box 458, Flemington, New Jersey 08823
}

\begin{abstract}
In April 1991, submarine volcanic eruptions initiated the formation of numerous hydrothermal vents between $9^{\circ} 45^{\prime}$ and $9^{\circ} 52^{\prime} \mathrm{N}$ along the crest of the East Pacific Rise (EPR). Dramatic changes in biological community structure and vent fluid chemistry have been documented throughout this region since the eruptive event. By April 2004, mussels (Bathymodiolus thermophilus) dominated the faunal assemblages at several of the vent sites formed during of after the 1991 eruptions, whereas other habitats within the region were dominated by the vestimentiferan Riftia pachyptila. In the present paper, we build upon the extensive data sets obtained at these sites over the past decade and describe a manipulative experiment (conducted at $9^{\circ} 49.94^{\prime} \mathrm{N}$; $104^{\circ} 14.43^{\prime} \mathrm{W}$ on the EPR) designed to assess interrelationships between vent fluid chemistry, temperature, biological community structure, and seismic activity. To this end, in situ voltammetric systems and thermal probes were used to measure $\mathrm{H}_{2} \mathrm{~S} / \mathrm{HS}^{-}$and temperature over time in a denuded region of an extensive mussel bed in which an exclusion cage was placed to inhibit the subsequent migration of mussels into the denuded area. Fluid samples were taken from the same locations to characterize the associated microbial constituents. Basalt blocks, which were placed in the cage in April 2004 and subsequently recovered in April 2005 , were colonized by more than 25 different species of invertebrates, including numerous vestimentiferans and remarkably few mussels. Recorded temporal changes in vent fluid chemistry and temperature regimes, when coupled with microbiological characterization of the vent fluids and seismic activity data obtained from ocean bottom seismometers, shed considerable light on factors controlling biological community structure in these hydrothermal ecosystems.
\end{abstract}

KEY WORDS: hydrothermal vents, seismicity, voltammetry, vent chemistry, mussels

\section{INTRODUCTION}

In November to December 1989 an extensive survey between $9^{\circ} 16^{\prime}$ and $9^{\circ} 54^{\prime} \mathrm{N}$ along the East Pacific Rise (EPR) was conducted using the ARGO-I optical acoustic system to image $80 \%$ of the axial summit collapse trough (ASCT) with video and $35 \mathrm{~mm}$ camera systems (Haymon et al. 1991a). A return visit to this region in April 1991 revealed that the distribution and character of vents and associated biological communities located between $9^{\circ} 45^{\prime}$ and $9^{\circ} 52^{\prime} \mathrm{N}$ along the EPR had been altered by volcanic eruptions since the ARGO-I survey. Well-developed faunal communities seen in ARGO-I images taken 15 mo earlier were buried by new lava flows at several sites along the floor of the ASCT. Evidence for extremely recent eruptive events in this region has been presented elsewhere (Rubin \& MacDougall 1991, Haymon et al. 1991b, Haymon et al. 1991c, Haymon et al. 1991d, Haymon et al. 1993, Von Damm 1991, Rubin et al. 1994), establishing, for the first time, a "time-zero" for a local eruption along a deep-sea ridge crest (Haymon et al. 1991b, Haymon et al. 1991c, Haymon et al. 1991d, Haymon et al. 1993). Of particular biological note was the presence of extensive areas of "low-temperature," diffuse vent flow with no characteristic vent megafauna but an abundance of thick, white "bacterial" mats

*Corresponding author. E-mail: lutz_richard@hotmail.com
(Nelson et al. 1991, Lutz et al. 1994, Lutz et al. 2001; Shank et al. 1998). The absence of these bacterial mat areas in $35 \mathrm{~mm}$ or video recordings taken 15 mo earlier using the ARGO imaging system suggested that these areas might represent early successional stages of vent colonization and afford a unique opportunity to follow temporal changes in vent community structure (Haymon et al. 1993, Lutz \& Haymon 1994). Since April 1991, deep-diving submersibles have returned to various regions between $9^{\circ} 45^{\prime}$ and $9^{\circ} 52^{\prime} \mathrm{N}$ along the EPR at least once a year. During the majority of these cruises, extensive imaging surveys, vent fluid chemistry analyses and time-lapse, temperature monitoring studies documented temporal changes occurring since the eruption and provided invaluable background data for the present study (Von Damm et al. 1994, Fornari et al. 1998, Shank et al. 1998). During March 1992, 210 markers were deployed between $9^{\circ} 49.64^{\prime}$ and $9^{\circ} 50.36^{\prime} \mathrm{N}$ along the EPR to facilitate future studies in the region (see Shank et al. 1998 for details). The present study, which was conducted in the region of Marker 119 located at $9^{\circ} 49.94^{\prime} \mathrm{N} ; 104^{\circ} 14.43^{\prime} \mathrm{W}$, summarizes results of an interdisciplinary study designed to assess interrelationships between vent fluid chemistry, temperature, seismic activity, and biological community structure at this vent site. This integrated study was originally designed as a multiyear effort; however, in January 2006 an extensive volcanic eruption on the seafloor completely obliterated the vent site in the 
Marker 119 region. All associated experiments and markers, as well as the majority of ocean bottom seismometers that were deployed throughout the region, were buried under fresh lava flows. As a result, we were only able to obtain data during two successive dive programs (one in April 2004 and the other in April 2005) with the deep-diving submersible Alvin. Despite the premature termination of our studies, results obtained provide many significant insights into the nature of chemical, physical and biological interrelationships at the site, yielding invaluable background data sets for future research efforts within this volcanically and tectonically active region of the midoceanic ridge crest.

\section{Hypotheses}

The specific hypotheses to be addressed by our outlined approach may be summarized as follows: (1) The presence of extensive numbers of mussels within selected regions of the vent faunal assemblage inhibits the colonization and subsequent growth of vestimentiferan tubeworms through depletion of $\mathrm{H}_{2} \mathrm{~S}$ below critical levels; (2) If mussels were to be removed and subsequently excluded from regions with elevated temperatures and $\mathrm{H}_{2} \mathrm{~S}$ concentrations within a mussel population at an active vent site along the East Pacific Rise, then the area will be colonized by numerous vent-endemic species, including Tevnia jerichonana and Riftia pachyptila, which reportedly represent "early vent colonizers"; see Shank et al. (1998); (3) During later stages of succession, as $\mathrm{H}_{2} \mathrm{~S}$ levels are reduced by the overlying mussel population, the vestimentiferan Oasisia alvinae remains as the last ("climax") vestimentiferan in and among the mussel population; (4) Seismic events will alter the chemistry and temperatures of diffuse hydrothermal vent fluids within the region; (5) Specific bacteria are repeatedly found in newlyestablished microbial filamentous communities from different diffuse flow vents within the general area of our study site along the EPR; and (6) Mesophilic facultative and obligate autotrophic microorganisms are important components of the microbial assemblages in diffuse vent flows and associated thermal plumes.

\section{Biological Community Structure}

After the April 1991 eruptive events, biological communities associated with numerous nascent hydrothermal vents between $9^{\circ} 49.64^{\prime}$ and $9^{\circ} 50.36^{\prime} \mathrm{N}$ along the EPR underwent successional changes from assemblages characterized by massive microbial mats and a few, small bythograeid crabs in April 1991 to ones characterized by large populations of mussels in April 2000. Details of these successional changes have been described by Shank et al. (1998) and Lutz et al. (2001) and we have documented further changes in community structure during various cruises to this portion of the EPR since April 2000. The successional changes in faunal community development that have occurred in the vicinity of Marker 119 from April 1991 through April 2004 are depicted in Figure 1.

\section{Vent Fluid Chemistry}

Shank et al. (1998) reported time-series fluid chemistry data, including maximum levels of $\mathrm{H}_{2} \mathrm{~S}$, from December 1993 to November 1995 at three separate hydrothermal vent sites within a kilometer of the Marker 119 site. From subsequent in situ voltammetric studies conducted by Luther et al. (2001a, $2001 \mathrm{~b}$ ), it is now recognized that the $\mathrm{H}_{2} \mathrm{~S}$ figures reported in Shank et al. (1998) actually represent values for total sulfide $\left(\mathrm{FeS}+\mathrm{H}_{2} \mathrm{~S} / \mathrm{HS}^{-}\right)$. At one of these sites, total sulfide values measured in December 1993, October 1994, and November 1995 were, respectively, $0.94,0.88$, and $0.72 \mathrm{mmol} / \mathrm{kg}$ (respective in situ temperatures of sampled fluids were $26^{\circ}, 29^{\circ}$, and $27^{\circ} \mathrm{C}$ ). At a second site, total sulfide values at these same times were, respectively, $0.98,0.68$, and $0.30 \mathrm{mmol} / \mathrm{kg}$ (respective in situ temperatures were $35^{\circ}, 28^{\circ}$, and $18^{\circ} \mathrm{C}$ ). At the third site, total sulfide values of 0.40 and $0.26 \mathrm{mmol} / \mathrm{kg}$ were measured in October 1994 and November 1995, respectively (respective in situ temperatures were $20^{\circ}$ and $18^{\circ} \mathrm{C}$ ). These total sulfide and temperature measurements were invariably taken from areas of maximum temperature within the community, at the base of vestimentiferan assemblages. In situ voltammetric studies (conducted in May 1999) of total sulfide and free $\mathrm{H}_{2} \mathrm{~S} / \mathrm{HS}^{-}$) have yielded maximum values of approximately 100 and $40 \mu \mathrm{mol} / 1$ (approximately 0.10 and $0.04 \mathrm{mmol} / \mathrm{kg}$ ), respectively, for fluids surrounding the plumes of Riftia in populations at another vent site, also within a kilometer of the Marker 119 site (in situ temperature of the fluids adjacent to the plumes was $8.5^{\circ} \mathrm{C}$ ) (Luther et al. 2001a). The lower sulfide values reflect the fact that measurements were made at the tubeworm plumes, which are a considerable distance above the base of the vestimentiferan tubes where temperature and sulfide values are higher. Earlier studies conducted in a variety of vent environments (Johnson et al. 1988a, Johnson et al. 1988b, Johnson et al. 1994) have generally shown a positive correlation between temperature and total sulfide concentration in diffuse flow fluids. However, in November 1995 vent fluids associated with a moribund colony of $R$. pachyptila approximately $0.5 \mathrm{~km}$ north of the Marker 119 site had a maximum temperature of $29^{\circ} \mathrm{C}$, but a total sulfide concentration below the detection limit $(3 \mu \mathrm{mol} / \mathrm{kg})$.

\section{Temperature Regimes}

Temperatures of hydrothermal vent fluids can provide important proxy measurements of the physical and chemical state of midocean ridge hydrothermal and magmatic phenomena and the effects they have on biological communities that inhabit these systems (Fornari et al. 1998, Scheirer et al. 2006). Since December 1993, there have been over 90 deployments of self-recording, time-lapse (Vemco) temperature probes to measure both long- and short-term spatial and temporal variability in vent fluid temperatures at various vents within a kilometer of the Marker 119 site, with individual probes recording up to 64,000 measurements per deployment. Spectral analyses of temperature profiles have been undertaken to determine the extent to which (1) coupling of temperature changes between high- and low-temperature fluids occurs; (2) recent fracturing of volcanic events influence low- and high-temperature venting (Fornari et al. 1998); (3) geochemical changes in vent fluids correlate with fluid temperature; and (4) temporal and spatial variations in biological community development within and between distant communities can be correlated with changing temperature regimes (Shank et al. 1998). Initial results from these analyses have been summarized by Shank et al. (1995, 1997) and Fornari et al. (1998) and more detailed analyses undertaken by Scheirer et al. (2006). These profiles provide invaluable background records of short- and long-term temperature 

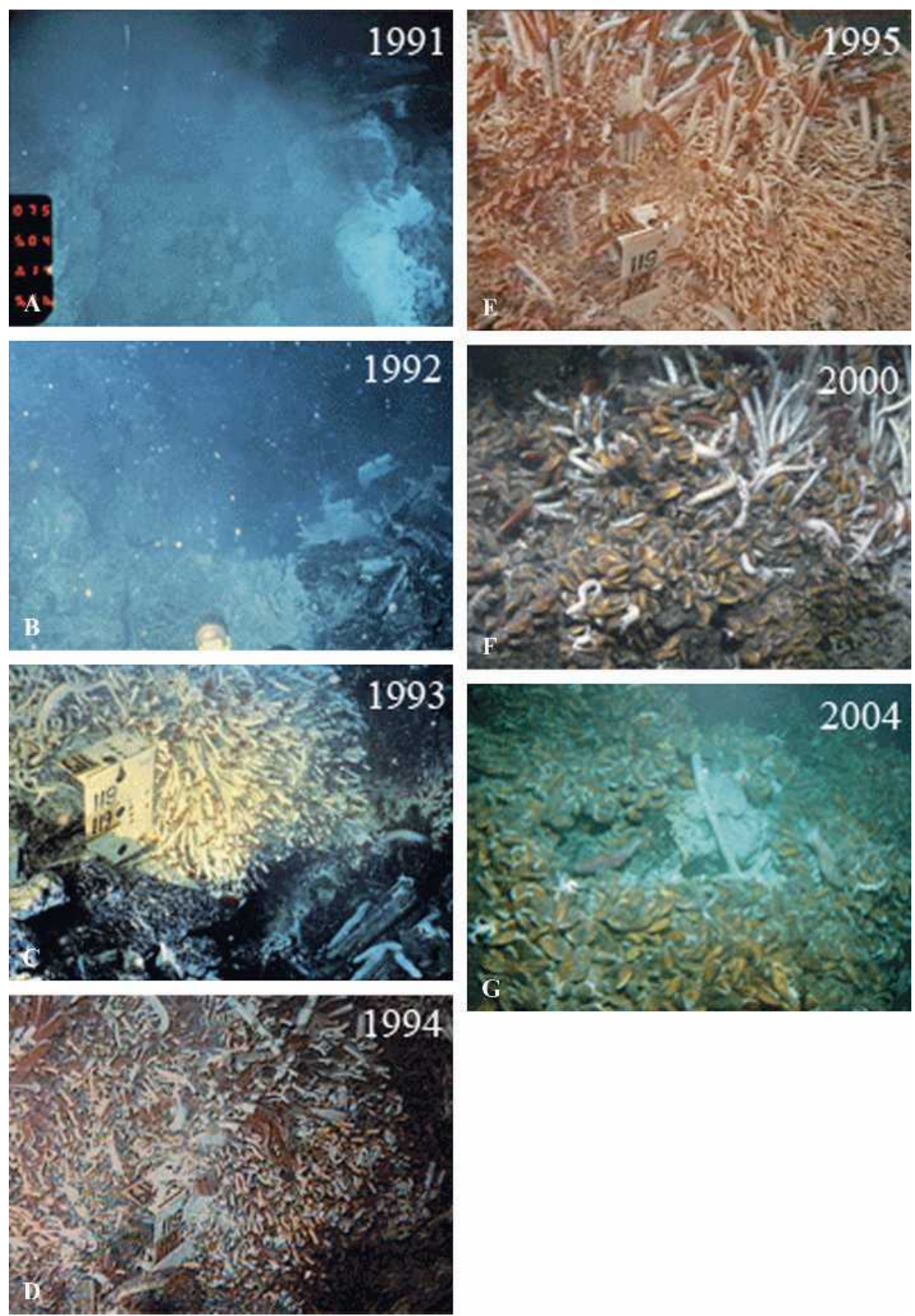

Figure 1. Succession of organisms around Marker 119 located at $9^{\circ} 49.94^{\prime} \mathrm{N} ; 104^{\circ} 14.43^{\prime} \mathrm{W}$ on the East Pacific Rise. Shortly after an eruptive event in April 1991, microbial mats began to form near the vents and pieces were ejected from the vent (a and b). Juvenile Tevnia jerichonana grew and proliferated within a year of the eruption but were gradually supplanted by the larger Riftia pachyptila (c and d). The mature Riftia community (e) supported perhaps the most biomass of any stage in this cycle. After $8 \mathrm{y}$, the mussel Bathymodiolus thermophilus had displaced many of the Riftia (f) and, by April 2004, eventually completely dominated the area with only a few remaining Riftia (g). Modified from Lutz et al. (2001).

variability at vents within the general region of the Marker 119 site for comparison with temperature measurements obtained in the present study.

\section{Microbiological Studies}

Microorganisms modify the vent chemical environment primarily through oxidation and reduction of sulfur and thereby play a fundamental role in altering hydrothermal fluids transported through porous substrates prior to contact with biological communities at the seafloor. Work on the isolation of bacteria from low-temperature, diffuse-flow vents was initially focused on sulfur oxidizers because of the predominance of reduced sulfur compounds in vent fluids (Ruby et al. 1981, Jannasch et al. 1985, Jannasch et al. 1989, Nelson et al. 1989). 
Many types of sulfur-oxidizing bacteria are found in dense microbial mats exposed to the hydrogen sulfide/oxygen interface. These mats generally consist of filamentous bacteria belonging to the $\gamma$ - and $\varepsilon$-Proteobacteria (Gundersen et al. 1992, Taylor \& Wirsen 1999). Recent reports suggest that the $\varepsilon$-Proteobacteria may play an important role in the biogeochemistry of deep-sea hydrothermal vent ecosystems (Corre et al. 2001, Longnecker \& Reysenbach, 2001, Campbell et al. 2001, Moyer et al. 1995). In particular, $\varepsilon$-Proteobacteria were found to largely dominate the microbial communities associated with the vent polychaeate Alvinella pompejana and tubeworm Riftia pachyptila on the EPR at both $9^{\circ}$ and $13^{\circ}$ North (Cary et al. 1997, Lopez-Garcia et al. 2002) and were abundant in microbial communities associated with a diffuse flow vent on the Juan de Fuca Ridge that was sampled at different times after an eruptive event (Huber et al. 2003). Finally, a culture-dependent analysis of diffuse flow vents on the Juan de Fuca Ridge showed that heterotrophic Halomonas spp. and Marinobacter spp. were the most abundant species that could be cultured in the laboratory (Kaye \& Baross 2000).

\section{Other Relevant Studies}

In addition to the studies outlined earlier, which have been conducted within the general area of the Marker 119 site, there have been several studies that provide essential background data and technological developments critical for testing our hypotheses outlined earlier. (1) Mullineaux et al. (2000) have shown that the presence of $T$. jerichonana may facilitate the settlement of other species of vestimentiferans. We hypothesize that the removal and subsequent exclusion of mussels from selected vent areas as part of our experimental design will facilitate the settlement of $T$. jerichonana and the subsequent colonization of these areas by the vestimentiferans $R$. pachyptila and Oasisia alvinae. (2) Lutz et al. (1994) have provided evidence that growth rates (increase in tube length per unit time) of the vestimentiferan $R$. pachyptila under certain conditions exceed $85 \mathrm{~cm} / \mathrm{yr}$. More recently, Thiebaut et al. (2002) have estimated that the tube growth rate of this species in certain populations within the vicinity of $9^{\circ} 50^{\prime} \mathrm{N}$ along the EPR may be as high as $160 \mathrm{~cm} / \mathrm{yr}$. The duration of the initial phase of our manipulative experiment described below (which, because of the January 2006 eruptive event, ultimately ended up being the entire duration of our experiment) focused on tubeworm colonization, survival and growth and ran from April 2004 to April 2005. Given the remarkably rapid growth rates reported in the above studies, it is reasonable to expect that significant tubeworm growth (up to several $\mathrm{mm} /$ day) could occur during the time interval of our outlined experiment. (3) Micheli et al. (2002), working at a variety of vent areas within the $9^{\circ} 50^{\prime} \mathrm{N}$ region, demonstrated that the use of cages with 6-mm plastic Vexar mesh provides an effective means of excluding predators such as zoarcid fish, crabs, whelks, and octopi. Caging experiments have illustrated that the abundance of small mobile grazers (e.g., gastropods) significantly increases within exclusion cages over time. Whereas such mobile grazers may directly consume newly-settled larvae and juveniles or may increase their postsettlement mortality, no statistically significant differences were found in the abundance of sessile invertebrates (e.g., mussels and vestimentiferans) on caged or uncaged substrates. (4) In the studies conducted by Mullineaux et al. (2000) and Micheli et al. (2002), caged and uncaged cubic basalt blocks (approximately $10 \mathrm{~cm}$ on each side) left in various diffuse flow vent environments for periods ranging from 5-13 mo were colonized by substantial numbers of vestimentiferans (up to 403 individuals over a 5-mo period and up to 731 individuals over a 13-mo period). (5) At the Rose Garden hydrothermal vent field along the Galapagos Spreading Center, Johnson et al. (1988a, 1994) made a spectrum of in situ measurements of vent fluid chemistry. Their system used a flow injection analysis technique to measure acid-volatile sulfide $\left(\mathrm{AVS}=\sum\left[\right.\right.$ free $\left.\left.\mathrm{H}_{2} \mathrm{~S} / \mathrm{HS}^{-}+\mathrm{FeS}\right]\right)(=$ total sulfide $)$, together with temperature, silicate and oxygen, before and after removal of mussels from selected regions of an extensive mussel population. In modest flows, such as those typical of many mussel habitats, the mussels reduced the sulfide content of the venting water as it passed through their aggregations. In a mussel "clearance" experiment, more than $50 \%$ of the total sulfide present in the hydrothermal source solutions seemed to be removed by the mussel community. The Rose Garden area had changed over a 9-y period (1979-1988) (see also, Hessler et al. 1988) from one dominated by vestimentiferans (Riftia pachyptila) to one dominated by mussels. Johnson et al. (1988a) evoked two hypotheses to account for the observed successional changes: (1) there are regular periods of low flow that would be accompanied by low temperature and limited availability of sulfide; the mussels divert sufficient sulfide under these conditions to "starve" the worms; and (2) the mussels may be able to physically displace or interfere with the worms through the mussels' growth in place, as well as their ability to move. The authors believed that both of these mechanisms may be important. In the present study, we build on these studies by measuring the biologically available (free) $\mathrm{H}_{2} \mathrm{~S} / \mathrm{HS}^{-}$using in situ voltammetric techniques recently developed by Luther et al. (2001a) and by conducting a manipulative organism removal, exclusion, and colonization experiment to assess the validity of the hypotheses proposed by Johnson et al. (1988a).

It is important to recognize that our conducted experiment is designed to build on the pathfinding experiments conducted by Mullineaux et al. (2000) and Micheli et al. (2002). Given the extensive replicates and controls that were used in their experimental design, there is no need to duplicate their design or retest any of the hypotheses that were so elegantly addressed by these authors. From their results, as well as from extensive measurements we have made in the region over the past decade, we recognize that the spatial and temporal heterogeneity of temperature and chemical regimes associated with the vent microhabitats at the site does not allow the deployment of multiple settlement substrates (i.e., basalt blocks) that could be considered true "replicates." Our experiment described later is thus designed to obtain in situ temperature and chemical measurements at each of our deployed basalt blocks and assess the associated recruitment and colonization of vent endemic organisms on the blocks over time to provide further insights into factors responsible for the results obtained by Mullineaux et al. (2000) and Micheli et al. (2002), as well as those obtained earlier by Johnson et al. (1988a, 1994).

\section{MATERIALS AND METHODS}

\section{Dates of Study}

Results summarized in the present paper were obtained during two separate cruises of the $R / V$ Atlantis, each with an 
associated DSV Alvin dive program, during April 2004 (Alvin Dives 3996-4012 from April 8 to April 24) and April-May 2005 (Alvin Dives 4099-4113 from April 23 to May 15).

\section{Exclusion Cage and Basalt Blocks}

A cage measuring approximately $0.75 \mathrm{~m}$ long $\times 0.75 \mathrm{~m}$ wide $\times 0.50 \mathrm{~m}$ high that was designed to inhibit the migration of mussels from adjacent populations to within or beneath the cage was constructed using PVC piping for the frame and $6 \mathrm{~mm}$ Vexar plastic mesh identical to that used by Micheli et al. (2002). A bottom weighted, fine-mesh "skirt," designed to conform to contours of the seafloor, was attached to the bottom of the cage to inhibit mussels from migrating under the cage after deployment at the Marker 119 site. Nine basalt cubes (measuring $10 \mathrm{~cm}$ on each side) identical to those used by Mullineaux et al. (2000) and Micheli et al. (2002) were evenly spaced within the cage in a $3 \times 3$ lattice arrangement. Figure 2 depicts the cage, with the associated basalt blocks inside, as seen on the front of the basket of $D S V$ Alvin just prior to launching the submersible for deployment of the cage on the bottom at the Marker 119 site.

\section{Seismic Monitoring}

Ten Ocean Bottom Seismometers (OBSs) were deployed in the vicinity of the Marker 119 site in an array depicted in Figure 3. The primary array of seven OBSs that had been continuously recording since October 2003 was supplemented by an additional three OBSs that were deployed in close proximity to Marker 119 from April 13 through April 19, 2004. The individual OBS instruments were subsequently recovered and the data downloaded and processed to record the number and magnitude of seismic events that occurred during the deployment period. Another primary array of nine OBSs recorded data from April 2004 through May 2005, the same general configuration as the 2003-2004 primary array.



Figure 2. The mussel exclusion cage on the basket of Alvin before deployment on the bottom at the Marker 119 study site. The nine basalt settlement blocks are kept in place with rubber bands and have a nylon rope attached to an embedded eyebolt for later retrieval with the manipulator arm of Alvin. The weighted, netted skirt around the bottom of the exclusion cage serves to seal the cage to the uneven seafloor, inhibiting the migration of mussels under the cage.
Arrival times of seismic $\mathrm{P}$ - and $\mathrm{S}$-phases recorded at individual OBSs were automatically picked from the seismograms and then associated with individual earthquakes using standard tools provided by the Incorporated Research Institutions for Seismology (IRIS). Each set of phase picks and associated earthquake was subsequently inspected and, if necessary, revised by hand to assure a high quality of the resulting earthquake bulletin. For the 2003-2004 data-set this involved revising phase picks for over 16,000 earthquakes recorded on up to 10 OBSs. Phase arrival time picks of 476 well-recorded earthquakes were inverted to determine the 1D velocity structure beneath the array. The layered $1 \mathrm{D}$ model was subsequently used to compute absolute hypocenter locations using the program Hypoinverse (Klein 2002), and high-precision relative locations using the double-difference algorithm HypoDD (Waldhauser \& Ellsworth 2000). The resulting catalog of earthquakes that occurred within the OBS array includes 7,071 events.

\section{Vent Fluid Chemistry Systems}

\section{In Situ Electrochemical Analyzers}

In situ analyses of vent fluids at the Marker 119 cage site were conducted using two different Analytical Instrument Systems, Inc. electrochemical systems. The first (Model AISISEA-I; hereafter referred to as the in situ voltammetric probe), which was used to obtain discrete measurements of $\sum \mathrm{H}_{2} \mathrm{~S} / \mathrm{HS}^{-}$ (hereafter referred to as $\mathrm{H}_{2} \mathrm{~S}$ ) and temperature during the April 2004 and April-May 2005 Alvin dive programs, is a voltammetric analyzer powered via a cable from Alvin (Nuzzio et al. 2002). This instrument contains a potentiostat and a multiplexer to monitor up to four electrodes one at a time; working details of the analyzer, as well as standardization and conditioning of the electrodes are described in Brendel and Luther (1995) and Luther et al. (2001a, 2001b, 2002). The voltammetry hardware is linked to an IBM-compatible computer inside Alvin's sphere. The working electrode wand or holder is constructed of Delrin, encasing a stainless steel handle, so that the manipulator (arm) can hold and deploy the electrodes without breaking them. The counter and reference electrodes were placed in the submersible's basket and were not moved. The second electrochemical system (Model AISISEA-II) is similar in design, but is modified to serve as a totally unattended in situ electrochemical analyzer (ISEA) (hereafter referred to as the ISEA system), which is powered by a separate battery pack. Every four minutes, the instrument runs a sequence of four cyclic voltammograms (taking approximately $10 \mathrm{sec}$ each) per electrode that are recorded and subsequently analyzed to generate $\mathrm{H}_{2} \mathrm{~S}$ values; analytical details may be found in Luther et al. (2001a, 2001b, 2002).

\section{Selective Mussel Removal and Discrete Exclusion Cage Measurements}

On April 10, 2004 Alvin's temperature probe was used to locate an area measuring approximately $1 \mathrm{~m} \times 1 \mathrm{~m}$, with elevated temperatures $\left(>5^{\circ} \mathrm{C}\right)$ in the midst of an extensive population of mussels (Bathymodiolus thermophilus). The in situ voltammetric probe was inserted as far as possible into a clump of mussels located approximately in the center of the $1 \mathrm{~m} \times 1 \mathrm{~m}$ area and the highest temperature and associated $\mathrm{H}_{2} \mathrm{~S}$ concentration measured were recorded. Mussels were then 


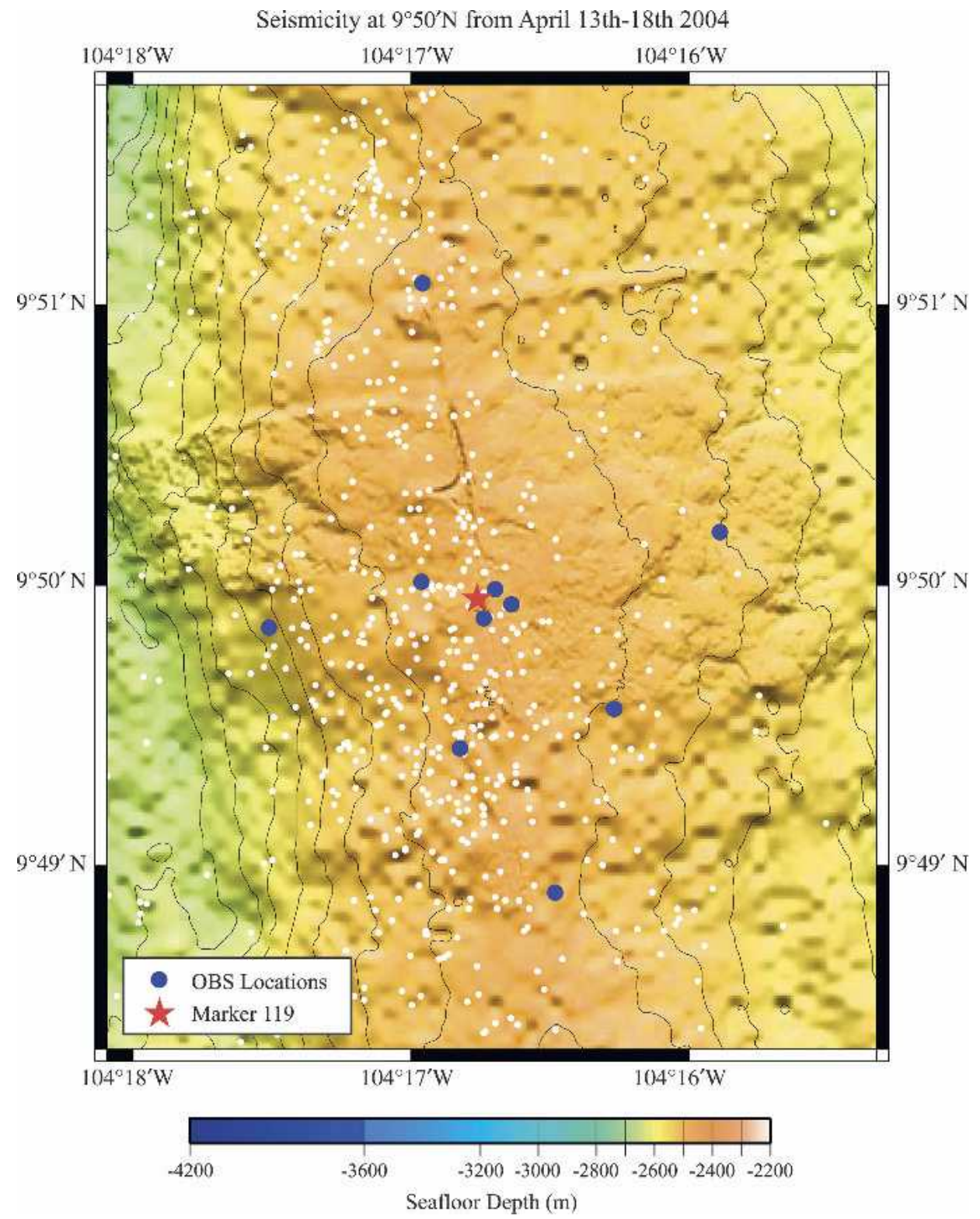

Figure 3. Seismicity recorded on the ocean bottom seismometer (OBS) array centered at $9^{\circ} 50^{\prime} \mathrm{N}$ on the East Pacific Rise. White dots indicate the locations of earthquakes recorded during the period of April 13th through April 18th, 2004. Events were all less than a magnitude 2.0 (ml) with most less than a magnitude $1.0(\mathrm{ml})$ - see Figures 5 and 6. Locations of OBSs are shown as blue circles, and the Marker 119 site is shown as a red star. Event locations are calculated using standard software provided by the Incorporated Research Institutions for Seismology (IRIS) based on a simple 1-D velocity model. The three OBSs closest to Marker 119 were deployed for approximately one week in conjunction with the focused vent fluid chemical and temperature monitoring at the site. The other OBSs were deployed as an array for $\mathbf{7}$ mo including this time period.

removed from the $1 \mathrm{~m} \times 1 \mathrm{~m}$ area, exposing the bare basalt, and the in situ voltammetric probe was used again to record the highest temperature and associated $\mathrm{H}_{2} \mathrm{~S}$ concentration found within the denuded area; the highest temperature encountered was located approximately in the center of the $1 \mathrm{~m} \times 1 \mathrm{~m}$ denuded area. The temperature and associated $\mathrm{H}_{2} \mathrm{~S}$ concentration in the water column $1 \mathrm{~m}$ above the approximate center of the $1 \mathrm{~m} \times 1 \mathrm{~m}$ area was also recorded. The exclusion cage was then placed directly over the denuded area. Temperatures and associated $\mathrm{H}_{2} \mathrm{~S}$ concentrations were measured at the base of each of the basalt blocks (Block \#s 1, 3, 7, and 9) located at the corners of the cage, as well as at the base of the basalt block
(Block \#5) located in the center of the cage. An identical series of temperature and $\mathrm{H}_{2} \mathrm{~S}$ concentration measurements were obtained at the base of each block that was recovered in April 2005 (see Basalt Block Recovery and Analysis section later), with the exception of Block \#7, at which measurements could not be obtained because of an electrical failure of the probe.

\section{In situ Chemistry and Temperature Measurements}

The autonomous ISEA system was deployed at the exclusion cage site from April 13-19, 2004 (Fig. 4). One of the system's electrodes, which was placed adjacent to the basalt block in the 


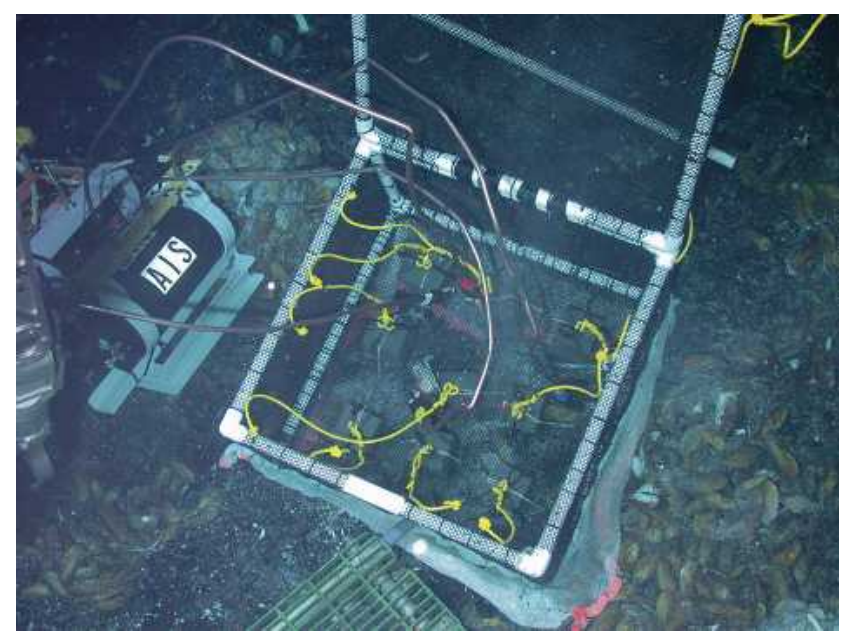

Figure 4. The in situ electrochemical analyzer (ISEA system) (left) with its associated voltammetric electrode system and time-lapse (Vemco) temperature probes. One of the system's electrodes, which was placed adjacent to the basalt block in the center of the cage (Block $\# 5$ ), successfully recorded the concentration of $\mathrm{H}_{2} \mathrm{~S}$ for an approximate 10-h period from 18:00 on April 14-04:00 on April 15, 2004, whereas the Vemco temperature probe, which was attached to the tip of this electrode, recorded a temperature every $8 \mathrm{sec}$ from April 13-18, 2004.

center of the cage (Block \#5), successfully recorded the concentration of $\mathrm{H}_{2} \mathrm{~S}$ for an approximate 10-h period from 18:00 on April 14-04:00 on April 15, 2004. The Vemco temperature probe, which was attached to the tip of the electrode, recorded a temperature every eight seconds from April 13-18, 2004.

\section{Microbiology}

\section{Collection of Samples}

Titanium bottles triggered using Alvin's manipulator were used to collect water samples at the source (seafloor) and $1 \mathrm{~m}$ above the source of the diffuse flow vent fluids at the Marker 119 cage site during both the April 2004 and April-May 2005 Alvin dive programs. Samples of microbial filaments were also collected from basalt block \#5 at the time it was retrieved on April 30, 2005 (see Basalt Block Recovery and Analysis section below). In situ temperatures and $\mathrm{H}_{2} \mathrm{~S}$ concentrations of the sampled fluids were measured at the time of sampling. Once on board the ship, samples were promptly transferred in the laboratory and subsamples were placed in stoppered tubes and stored at $4^{\circ} \mathrm{C}$.

\section{Isolation and Characterization of Pure Cultures}

Autotrophic, thiosulfate-oxidizing bacteria were isolated and routinely grown in a variation of medium 142 (http://www. dsmz.de/microorganisms/html/media/medium000142.html), which contained: $\mathrm{NaCl}, 25.0 \mathrm{~g} / \mathrm{L} ; \mathrm{MgSO}_{4} .7 \mathrm{H}_{2} \mathrm{O}, 1.5 \mathrm{~g} / \mathrm{L}$; $\left(\mathrm{NH}_{4}\right)_{2} \mathrm{SO}_{4}, 1.0 \mathrm{~g} / \mathrm{L} ; \mathrm{KCl}, 0.64 \mathrm{~g} / \mathrm{L} ; \mathrm{CaCl}_{2} 2 \mathrm{H}_{2} \mathrm{O}, 0.42 \mathrm{~g} / \mathrm{L}$; $\mathrm{NaHCO}_{3}, 0.046 \mathrm{~g} / \mathrm{L} ; \mathrm{KH}_{2} \mathrm{PO}_{4}, 0.5 \mathrm{~g} / \mathrm{L} ; \mathrm{Na}_{2} \mathrm{~S}_{2} \mathrm{O}_{3}, 5.0 \mathrm{~g} / \mathrm{L}$; vitamin $\mathrm{B}_{12}, 15 \mathrm{~g} / \mathrm{L} ; 1 \mathrm{~mL}$ of a trace element solution containing: $\mathrm{FeSO}_{4} \cdot 7 \mathrm{H}_{2} \mathrm{O}, 2.1 \mathrm{~g} / \mathrm{L} ; \mathrm{MnCl}_{2} \cdot 4 \mathrm{H}_{2} \mathrm{O}, 100 \mathrm{mg} / \mathrm{L} ; \mathrm{CoCl}_{2} \cdot 6 \mathrm{H}_{2} \mathrm{O}$, $190 \mathrm{mg} / \mathrm{L} ; \mathrm{ZnSO}_{4} \cdot 7 \mathrm{H}_{2} \mathrm{O}, 144 \mathrm{mg} / \mathrm{L} ; \mathrm{H}_{3} \mathrm{BO}_{3}, 6 \mathrm{mg} / \mathrm{L} ; \mathrm{NiCl}_{2} \cdot 6$ $\mathrm{H}_{2} \mathrm{O}, 24 \mathrm{mg} / \mathrm{L}$; and $\mathrm{Na}_{2} \mathrm{MoO}_{4} \cdot 2 \mathrm{H}_{2} \mathrm{O}, 36 \mathrm{mg} / \mathrm{L}$; and $8.5 \mathrm{~mL}$ of $37 \% \mathrm{HCl}$. The $\mathrm{pH}$ of the medium was adjusted to 7.2 with a sterile solution of $\mathrm{Na}_{2} \mathrm{CO}_{3}(0.4 \% \mathrm{w} / \mathrm{v})$. For growth of hetero- trophic organisms, the medium was supplemented with $10 \mathrm{mM}$ acetate. When necessary, the medium was solidified by adding Nobel agar $(15 \mathrm{~g} / \mathrm{L})$. Enrichment cultures were initiated shipboard by inoculating an aliquot $(0.1 \mathrm{~mL})$ of each sample in liquid medium, and pure cultures were obtained by repeated isolations of single colonies on solid medium. To facilitate the isolation of quantitatively representative organisms, in some cases the isolation of pure cultures was initiated from serial dilutions of primary enrichments. All culture experiments were carried out at temperatures ranging between $28^{\circ} \mathrm{C}$ and $47^{\circ} \mathrm{C}$.

\section{Basalt Block Recovery and Analysis}

Five (Block \#'s 2, 3, 5, 7, and 9) of the 9 blocks within the exclusion cage were recovered on April 30, 2005 and placed in individual containers identical to those used by Micheli et al. (2002) to insure retrieval of all associated organisms. Once on board the ship, the basalt blocks were immediately placed in the ship's constant temperature room at $4^{\circ} \mathrm{C}$. Microbial filaments that were evident on the block recovered from the center of the cage (Block \#5) were removed for subsequent microbiological characterization and all metazoan colonists were sorted and counted under the dissecting microscope. Organisms too small for unambiguous morphological identification were frozen and placed in an ultra-low freezer on board the ship for subsequent identification using a variety of molecular techniques (e.g., DNA extraction, targeted gene region amplification, restriction fragment length polymorphism (RFLP) analyses; see Shiozawa et al. 1992, France \& Kocher 1996, Dowling et al. 1996, Comtet et al. 2000) routinely used in the laboratory of one of the authors (TS). In addition to these more standard molecular techniques, an amplified fragment length polymorphism (AFLP; Vos et al. 1995) genotyping technique that has been successfully used to identify even larval stages of vent organisms was used as necessary for identification purposes (Shank \& Halanych 2007).

\section{RESULTS AND DISCUSSION}

\section{Seismicity}

The 2004-2005 seismic dataset indicates a gradual ramping up of activity levels between the 2004 and 2005 experiments, with average background activity levels being on the order of 100 events per day in April 2004, and on the order of 500 events per day by April 2005. This apparent long-term trend is superimposed by short-term fluctuations in seismicity rate, most likely associated with swarm-like activity. As suggested by Tolstoy et al. (2006), the gradually increasing number of events per day from April 2004 to April 2005 might well portend the January 2006 eruption.

\section{Vent Fluid Chemistry and Temperature}

Selective Mussel Removal and Discrete Exclusion Cage Measurements

The highest temperatures and associated $\mathrm{H}_{2} \mathrm{~S}$ concentrations measured at approximately the center of the $1 \mathrm{~m} \times 1 \mathrm{~m}$ exclusion cage site before and after removal of mussels on April 10, 2004 (see Materials and Methods section for details) are summarized in Table 1, together with the temperatures and $\mathrm{H}_{2} \mathrm{~S}$ concentrations in the water column $1 \mathrm{~m}$ above the approximate 
TABLE 1.

Temperature and hydrogen sulfide concentrations before and after removing the mussels from the exclusion cage site at Marker 119 in April 2004.

\begin{tabular}{lccccc}
\hline \hline & \multicolumn{2}{c}{ Before Removing Mussels } & \multicolumn{2}{c}{ After Removing Mussels } \\
\cline { 2 - 3 } & Temperature $\left({ }^{\circ} \mathbf{C}\right)$ & $\mathbf{H}_{\mathbf{2}} \mathbf{S}(\boldsymbol{\mu m o l} / \mathbf{L})$ & & Temperature $\left({ }^{\circ} \mathbf{C}\right)$ & $\mathbf{H}_{\mathbf{2}} \mathbf{S}(\boldsymbol{\mu m o l} / \mathbf{L})$ \\
\hline Seafloor & $7.9 \pm 0.5$ & 43.30 & $13.9 \pm 0.5$ & 73.67 \\
1 m above seafloor & $2.4 \pm 0.5$ & 0.60 & $1.5 \pm 0.5$ & 0.00 \\
\hline
\end{tabular}

center of the $1 \mathrm{~m} \times 1 \mathrm{~m}$ area before and after mussel removal. The measured increase in the highest temperature from $7.9 \pm$ $0.5^{\circ} \mathrm{C}$ to $13.9 \pm 0.5^{\circ} \mathrm{C}$ and the associated increase in the concentration of $\mathrm{H}_{2} \mathrm{~S}$ from $43.30-73.67 \mu \mathrm{mol} / \mathrm{L}$ at the source of the diffuse flow vent fluids (seafloor) are consistent with the results from the mussel "clearance" experiment reported by Johnson et al. (1988a, 1994), which suggested that a substantial quantity of the total sulfide present in the hydrothermal source solutions at a vent field along the Galapagos Rift was removed by the mussel community. The postcage-deployment temperatures and associated $\mathrm{H}_{2} \mathrm{~S}$ concentrations at the base of each of the basalt blocks (Block \#s 1, 3, 7, and 9) located at the corners of the cage, as well as at the base of the block (Block \#5) located in the center of the cage are summarized in Table 2. The lower temperature $\left(12.8 \pm 0.5^{\circ} \mathrm{C}\right)$ and $\mathrm{H}_{2} \mathrm{~S}(34.76 \mu \mathrm{mol} / \mathrm{L})$ values measured at the center of the cage (base of Block \#5) relative to the temperature and $\mathrm{H}_{2} \mathrm{~S}$ values reported in Table 1 "after removing mussels" are likely a reflection of the fact that the Vexar mesh on the bottom of the cage resulted in an elevation of Block \#5 a few centimeters above the seafloor where diffuse flow temperatures and sulfide concentrations should be higher.

In situ Chemistry and Temperature Measurements Correlated with Seismic Activity

Earthquakes can potentially influence fluid chemistry and temperature in a number of ways. The small earthquakes observed represent tiny cracking events related to tectonic stresses, magma-induced stresses, or hydrothermal cooling. These events can impact the fluids either directly by impacting flow patterns or indirectly be changing the stress fields through the passage of seismic waves. A distant event can have a significant impact if it is of large enough magnitude, and a very small event can have a significant impact if it directly impacts the path of the fluid being monitored. Figure 5 depicts the magnitude of the total number of seismic events (as well as the magnitude of events within $1 \mathrm{~km}$ of the Marker 119 site) from the period April 13-19, 2004, together with vent fluid temperatures (adjacent to Basalt Block $\# 5$ at the center of the exclusion cage) and the modeled tidal amplitude during this same period. Of particular note is that, from April 13 to April 15, the higher average temperatures appear to correlate with the higher number and magnitude of seismic events occurring during this time period. However, whereas these preliminary, short-term data sets offer some intriguing hints of correlations between the magnitude and number of seismic events, vent fluid temperatures, and tidal periodicities, further studies and detailed analyses of longerterm data sets are necessary to confirm the existence of statistically significant correlations. The number (per $15 \mathrm{~min}$ bin) and magnitude of seismic events (total number of events, as well as those within $1 \mathrm{~km}$ of the Marker 119 site) recorded by the OBS array, vent fluid temperatures, and vent fluid $\mathrm{H}_{2} \mathrm{~S}$ concentrations during an approximate 10-h period from 18:00 on April 14-04:00 on April 15, 2004 are graphically depicted in Figure 6.

Whereas the concentration of $\mathrm{H}_{2} \mathrm{~S}$ frequently positively covaries with temperature, there is a very poor correlation coefficient $\left(\mathrm{r}^{2}=0.03\right)$; it is obvious from examination of the graphs that the relationship between temperature and the $\mathrm{H}_{2} \mathrm{~S}$ concentration of the vent fluids at this site is complex. Temporal changes in bottom currents passing over the ISEA system's electrode and the attached Vemco temperature probe, which were adjacent to the basalt block, also undoubtedly contributed to the observed variation in both $\mathrm{H}_{2} \mathrm{~S}$ concentrations and temperatures. Notwithstanding such complexities, there are hints in the data presented in Figure 6 of relationships between seismic activity and the vent fluid $\mathrm{H}_{2} \mathrm{~S}$ concentration. The top graph in this figure depicts three seismic events (black dots) within $1 \mathrm{~km}$ of the Marker 119 site that occur near 01:00. These events occur 12-16 min before three prominent peaks in the

TABLE 2.

Temperature and hydrogen sulfide concentrations measured at the base of individual basalt blocks within the exclusion cage in April 2004 and April 2005.

\begin{tabular}{|c|c|c|c|c|}
\hline & \multicolumn{2}{|c|}{2004} & \multicolumn{2}{|c|}{2005} \\
\hline & Temperature $\left({ }^{\circ} \mathrm{C}\right)$ & $\mathrm{H}_{2} \mathrm{~S}(\mu \mathrm{mol} / \mathrm{L})$ & Temperature $\left({ }^{\circ} \mathrm{C}\right)$ & $\mathrm{H}_{2} \mathrm{~S}(\mu \mathrm{mol} / \mathrm{L})$ \\
\hline Block 2 & NA & NA & $6.9 \pm 0.5$ & 24.94 \\
\hline Block 3 & $3.9 \pm 0.5$ & 9.02 & $3.4 \pm 0.5$ & 4.41 \\
\hline Block 5 & $12.8 \pm 0.5$ & 34.76 & $7.6 \pm 0.5$ & 22.62 \\
\hline Block 7 & $2.5 \pm 0.5$ & 2.45 & NA & NA \\
\hline Block 9 & $2.1 \pm 0.5$ & 0.00 & $1.3 \pm 0.5$ & 0.0 \\
\hline
\end{tabular}



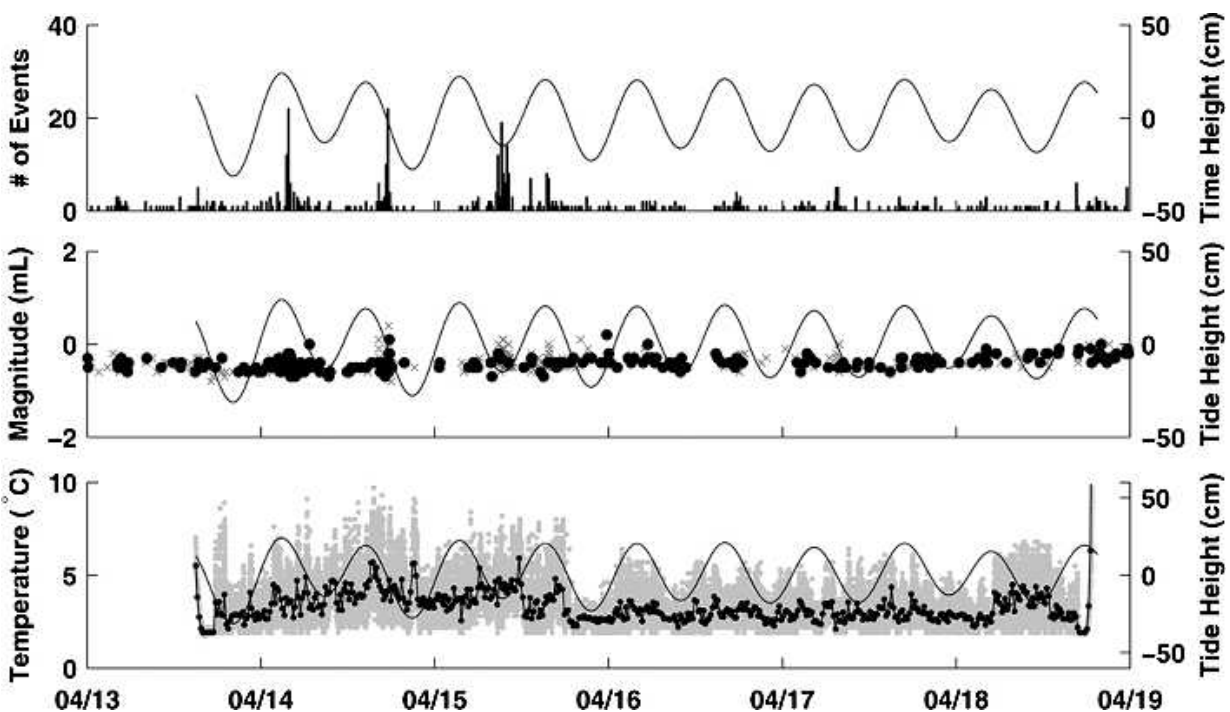

Figure 5. The total number of seismic events recorded by the OBS array in $15 \mathrm{~min}$ bins (top graph, bars), the magnitude of seismic events within the OBS array (grey x's) and the magnitude of seismic events within $1 \mathrm{~km}$ of the Marker 119 site (black dots) recorded by the OBS array (middle graph), vent fluid temperatures (bottom graph: grey circles are individual temperature measurements, whereas the solid line connects points representing the mean temperature for each $15 \mathrm{~min}$ bin), and modeled tidal amplitude (all graphs, solid black curves) from April 13-19, 2004. Temperature data were collected at 8-sec intervals using a Vemco temperature probe, which was attached to a microelectrode associated with the ISEA system and positioned adjacent to the basalt block (Block \#5) in the center of the cage. Note that from April 13-15, the higher average temperatures appear to correlate with the higher number and magnitude of seismic events occurring during this time period.

concentration of $\mathrm{H}_{2} \mathrm{~S}$ depicted in the bottom graph (differences in offset time may be, in part, because of the sampling frequency of the ISEA system electrodes). It is also worth noting that a peak in the concentration of sulfide that occurs at approxi- mately 01:40 is correlated with the highest seismic event magnitudes (as well as with a relatively large number of seismic events) recorded during the 10 -h period that the ISEA system was functioning. Finally, increased numbers and magnitudes of
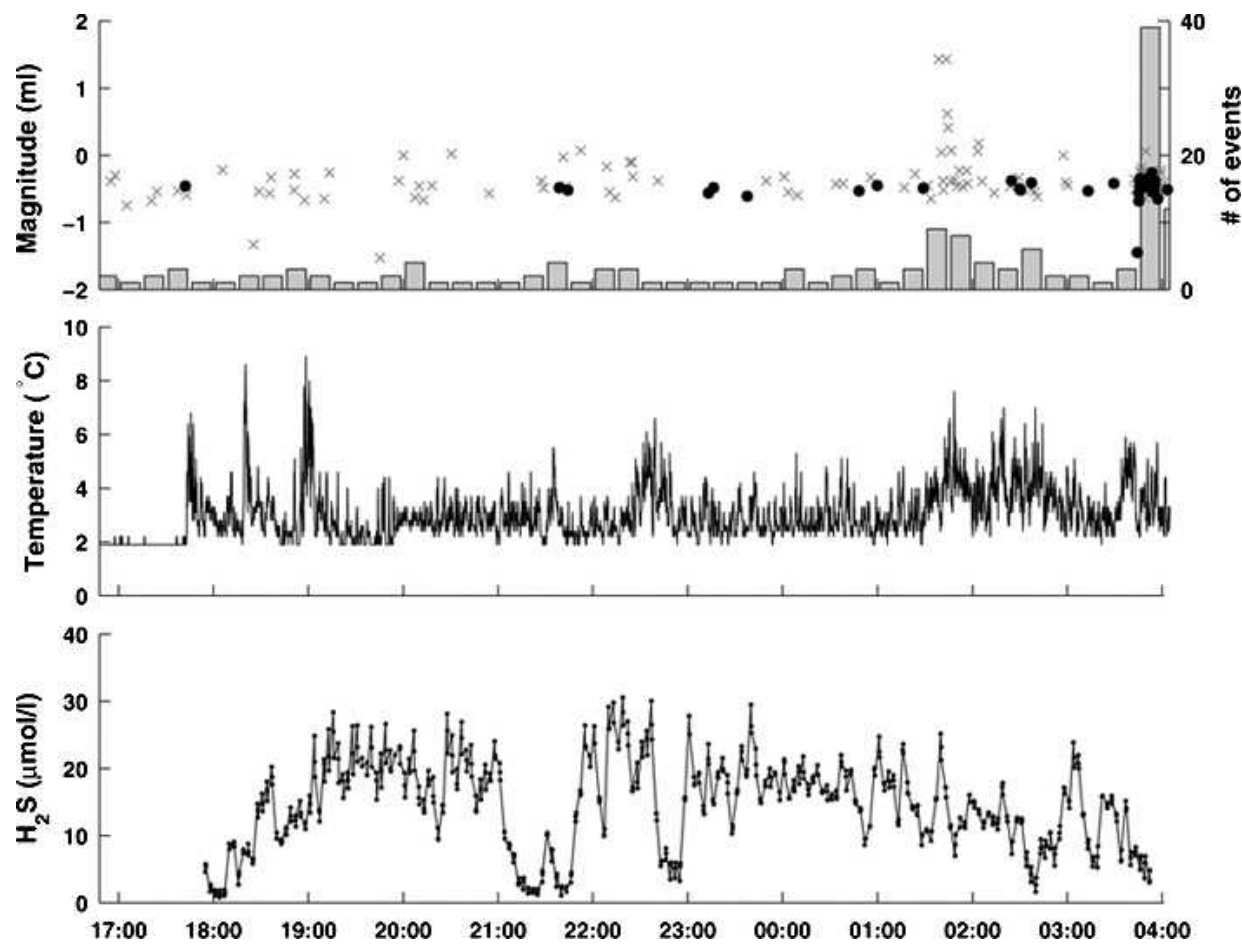

Figure 6. The number of seismic events in $15 \mathrm{~min}$ bins recorded by the OBS array (top graph, grey bars), the magnitude of seismic events within the OBS array (top graph, grey x's) and the magnitude of seismic events within $1 \mathrm{~km}$ of the Marker 119 site (top graph, black dots) recorded by the OBS array, vent fluid temperatures (middle graph), and vent fluid $\mathrm{H}_{2} \mathrm{~S}$ concentrations (bottom graph) during an approximate 10-h period from 18:00 on April 1404:00 on April 15, 2004. Temperature values were obtained at 8-sec intervals. Every 4 min, four cyclic voltammograms (taking approximately $10 \mathrm{sec}$ each) were recorded and subsequently analyzed to generate the plotted $\mathrm{H}_{2} \mathrm{~S}$ values. 
seismic events just prior to $02: 00$ are correlated with a relatively broad and pronounced peak in temperatures recorded at approximately this same time. Again, whereas these data are certainly very preliminary and not statistically significant because of the short monitoring period, further studies focused on potential relationships between seismic activity and vent fluid chemistry, and temperature are clearly warranted.

\section{Microbiological Studies}

Microorganisms isolated from water samples collected at the seafloor and $1 \mathrm{~m}$ above the seafloor before and after removing mussels from the $1 \mathrm{~m} \times 1 \mathrm{~m}$ exclusion cage site, together with associated in situ temperatures and $\mathrm{H}_{2} \mathrm{~S}$ concentrations of the sampled fluids, are summarized in Table 3 . A total of 14 pure cultures were isolated from fluid samples collected at the Marker 119 site. All isolations were carried out under aerobic conditions. Out of the 14 organisms, 7 were isolated from fluids collected at the source of the vent, and six were isolated from fluids collected $1 \mathrm{~m}$ above the seafloor. Eight out of 14 organisms were isolated under conditions that facilitated the growth of heterotrophic bacteria (i.e., medium 142 supplemented with $10 \mathrm{mM}$ acetate). These heterotrophic bacteria were predominantly represented by the genus Pseudomonas ( $P$. stutzeri appeared to be the closest relative to the vent isolates), although members of the genera Alcanivorax and Marinobacter were also isolated (Table 3 ). The remaining seven pure cultures were isolated under conditions that only allowed for growth of organisms that coupled carbon dioxide fixation to the oxidation of thiosulfate (Table 3). Strictly autotrophic organisms were related to members of the genera Thioclava, Thiomicrospira, and Halothiobacillus, whereas facultative autotrophs were related to the genera Halomonas and Salinisphaera. Based on analyses of the sequence similarity of the $16 \mathrm{~S}$ rRNA genes, we calculated that the sequence similarity of strains EPR 70 and EPR 71 to their closest relative, Salinisphaera shabanensis (a moderately halophilic bacterium that was recently isolated from the brine-seawater interface of the Shaban Deep in the Red Sea [Antunes et al. 2003]), was only 95\%. Therefore, we concluded that these bacteria represent a yet-to-be-described species (and possibly a new genus) of the Gammaproteobacteria. Detailed studies aimed at the description of these novel bacteria, isolated from the source fluids and those collected $1 \mathrm{~m}$ above the seafloor at the Marker 119 site are currently underway. Serial dilutions of primary enrichments for autotrophic bacteria resulted in the isolations of Thiomicrospira and Halomonas species (from $10^{-3}$ and $10^{-4}$ dilutions, respectively), suggesting that these bacteria are relatively abundant in the hydrothermal

TABLE 3.

Microorganisms isolated from water samples collected at the seafloor and $\mathbf{1} \mathbf{~ m}$ above the seafloor before and after removing mussels from the exclusion cage site in April 2004.

\begin{tabular}{|c|c|c|c|c|}
\hline Sample Location & Strain & Closest Relative $^{1}$ & Growth T & Autotrophy \\
\hline \multicolumn{5}{|l|}{2004} \\
\hline \multicolumn{5}{|l|}{ Seafloor } \\
\hline Before mussel removal & EPR44 & Pseudomonas sp. & $28^{\circ} \mathrm{C}$ & $\mathrm{No}^{2}$ \\
\hline $\mathrm{T}: 7.9 \pm 0.5^{\circ} \mathrm{C}$ & EPR48 & Pseudomonas sp. & $28^{\circ} \mathrm{C}$ & No \\
\hline \multirow[t]{4}{*}{$\mathrm{H}_{2} \mathrm{~S}: 43.30 \mu \mathrm{mol} / \mathrm{L}$} & EPR56 & Pseudomonas sp. & $28^{\circ} \mathrm{C}$ & No \\
\hline & EPR68 & Thioclava sp. & $28^{\circ} \mathrm{C}$ & Obligate \\
\hline & EPR70 & Salinisphaera sp. & $28^{\circ} \mathrm{C}$ & Facultative \\
\hline & EPR82 & Marinobacter sp. & $47^{\circ} \mathrm{C}$ & No \\
\hline \multicolumn{5}{|l|}{2004} \\
\hline \multicolumn{5}{|l|}{$1 \mathrm{~m}$ above seafloor } \\
\hline Before mussel removal & EPR49 & Alcanivorax sp. & $28^{\circ} \mathrm{C}$ & No \\
\hline $\mathrm{T}: 2.4 \pm 0.5^{\circ} \mathrm{C}$ & EPR71 & Salinisphaera sp. & $28^{\circ} \mathrm{C}$ & Facultative \\
\hline \multicolumn{5}{|l|}{$\mathrm{H}_{2} \mathrm{~S}: 0.60 \mu \mathrm{mol} / \mathrm{L}$} \\
\hline \multicolumn{5}{|l|}{2004} \\
\hline \multicolumn{5}{|l|}{ Seafloor } \\
\hline After mussel removal & EPR53 & Pseudomonas sp. & $28^{\circ} \mathrm{C}$ & No \\
\hline \multicolumn{5}{|l|}{$\mathrm{T}: 13.9 \pm 0.5^{\circ} \mathrm{C}$} \\
\hline \multicolumn{5}{|l|}{$\mathrm{H}_{2} \mathrm{~S}: 73.67 \mu \mathrm{mol} / \mathrm{L}$} \\
\hline \multicolumn{5}{|l|}{2004} \\
\hline \multicolumn{5}{|l|}{$1 \mathrm{~m}$ above seafloor } \\
\hline After mussel removal & EPR55 & Pseudomonas sp. & $28^{\circ} \mathrm{C}$ & No \\
\hline $\mathrm{T}: 1.5 \pm 0.5^{\circ} \mathrm{C}$ & EPR63 & Thioclava sp. & $28^{\circ} \mathrm{C}$ & Obligate \\
\hline \multirow{2}{*}{$\mathrm{H}_{2} \mathrm{~S}: 0 \mu \mathrm{mol} / \mathrm{L}$} & EPR77 & Thiomicrospira sp. & $30^{\circ} \mathrm{C}$ & Obligate \\
\hline & EPR84 & Halomonas sp. & $30^{\circ} \mathrm{C}$ & Facultative \\
\hline \multicolumn{5}{|l|}{2005} \\
\hline \multicolumn{5}{|c|}{ Filaments on block \#5 in cage } \\
\hline $\mathrm{T}: 7.6 \pm 0.5^{\circ} \mathrm{C}$ & EPR94 & Halothiobacillus sp. & $30^{\circ} \mathrm{C}$ & Obligate \\
\hline $\mathrm{H}_{2} \mathrm{~S}: 22.62 \mu \mathrm{mol} / \mathrm{L}$ & & & & \\
\hline
\end{tabular}

\footnotetext{
${ }^{1}$ Identified based on their $16 \mathrm{~S}$ rRNA gene sequence similarities with EPR strains
}

${ }^{2}$ Indicated inability to fix $\mathrm{CO}_{2}$ 
fluids at the Marker 119 site. The acetate-utilizing, heterotrophic bacteria that were isolated most frequently from both the source (seafloor) fluids and those $1 \mathrm{~m}$ above the seafloor at the Marker 119 site were members of the genus Pseudomonas. These bacteria grow at relatively fast rates and, therefore, they are likely to out compete slower-growing organisms. Within the autotrophic cultures, Halomonas, Halothiobacillus and Thiomicrospira species were previously isolated from deep-sea hydrothermal vent environments (Jannasch et al. 1985, Durand et al. 1993, Wirsen et al. 1998, Kaye \& Baross 2000, Kaye et al. 2004), whereas Thioclava pacifica was previously isolated from a shallow-water marine geothermal system in Papua New Guinea (Sorokin et al. 2005). Furthermore, organisms related to Halothiobacillus hydrothermalis (Durand et al. 1993) were cultured from samples of filamentous bacteria collected from the surface of basalt Block \#5, as well as from the surface of other natural substrates in vent areas (e.g., in a microbial mat growing on native basalt in a nearby hydrothermal vent area at $9^{\circ} 50^{\prime} \mathrm{N}$ ) and on various pieces of scientific equipment deployed within diffuse vent flows in adjacent areas for periods of approximately 1 y. Overall, we did not detect significant differences in the types of microorganisms that were isolated from samples collected at the seafloor and $1 \mathrm{~m}$ above the seafloor, or prior and after the removal of mussels from the Marker 119 area.

\section{Basalt Block Analyses}

Only 3 unidentified serpulids were present on Block \#7 and only one unidentified gastropod and 2 unidentified cnidarians (all potentially nonvent-endemic species) were present on Block \#9; the temperatures measured at the base of these blocks in both April 2004 and April 2005 ranged from $1.3 \pm 0.5^{\circ} \mathrm{C}$ to $2.5 \pm$ $0.5^{\circ} \mathrm{C}$ (with associated $\mathrm{H}_{2} \mathrm{~S}$ values ranging from below detection limits to $2.45 \mu \mathrm{mol} / \mathrm{L}$ ) and were the lowest associated with any of the five recovered blocks (Tables 2 and 4). Organisms present on Blocks \#2, \#3, and \#5 are summarized in Table 4. Of particular note were the presence of 2 specimens of Tevnia on Block \#5, the presence of 50,1, and 15 specimens of Riftia on Blocks \#2, \#3, and \#5, respectively; and the presence 3 specimens of Oasisia alvinae on Block \#5. Also notable was the remarkably few number of mussels (Bathymodiolus thermophilus) on any of the blocks (only one mussel present on Block \#3, one on Block \#5, and none on any of the other blocks). These findings are consistent with the two hypotheses evoked by Johnson et al. (1988a) that: (1) there are regular periods of low flow that would be accompanied by low temperature and limited availability of sulfide; the mussels divert sufficient sulfide under these conditions to "starve" vestimentiferans; and (2) the mussels may be able to physically displace or interfere with the vestimentiferans through the mussels' growth in place, as well as their ability to move. Thus, despite the unfortunate, premature termination of our experiment, which was destroyed by the January 2006 eruption, our preliminary results suggest that the removal and subsequent exclusion of mussels from a region of elevated temperatures and $\mathrm{H}_{2} \mathrm{~S}$ concentrations within a mussel population inhabiting an active vent site has permitted the colonization and subsequent growth of two species of vestimentiferans ( $T$. jerichonana and $R$. pachyptila) that otherwise would have been unable to colonize and grow at this site because of the presence of large numbers of mussels.
TABLE 4.

Species abundances of fauna present on individual basalt blocks placed in the exclusion cage at the Marker 119 site in April 2004 and recovered 1 y later in April 2005.

\begin{tabular}{lrrrrc}
\hline \hline & Block & Block & Block & Block & Block \\
& $\mathbf{2}$ & $\mathbf{3}$ & $\mathbf{5}$ & $\mathbf{7}$ & $\mathbf{9}$ \\
\hline Riftia pachyptila & 50 & 1 & 15 & 0 & 0 \\
Tevnia jerichonana & 0 & 0 & 2 & 0 & 0 \\
Oasisia alvinae & 0 & 0 & 3 & 0 & 0 \\
Nicomache venticola & 1 & 0 & 0 & 0 & 0 \\
Amphisamytha galapagensis & 59 & 3 & 7 & 0 & 0 \\
Ophryotrocha akessoni & 57 & 3 & 16 & 0 & 0 \\
Archinome rosacea & 3 & 0 & 2 & 0 & 0 \\
Branchipolynoe symmytilida & 0 & 0 & 1 & 0 & 0 \\
Lepidonotopodium williamsae & 0 & 0 & 1 & 0 & 0 \\
Eulepetopsis vitrea & 3 & 11 & 8 & 0 & 0 \\
Lepetodrilus ovalis & 29 & 42 & 16 & 0 & 0 \\
Lepetodrilus elevatus & 226 & 441 & 260 & 0 & 0 \\
Lepetodrilus pustulosus & 16 & 47 & 0 & 0 & 0 \\
Rhynchopelta concentrica & 5 & 0 & 0 & 0 & 0 \\
Provanna sp. & 1 & 0 & 0 & 0 & 0 \\
Cyathermia naticoides & 0 & 0 & 77 & 0 & 0 \\
Phymorhynchus major & 0 & 0 & 1 & 0 & 0 \\
Bathymodiolous thermophilus & 0 & 1 & 1 & 0 & 0 \\
Ventiella sulfuris & 11 & 67 & 54 & 0 & 0 \\
Levensteinella sp. & 0 & 3 & 0 & 0 & 0 \\
Dahlella calderiensis & 0 & 0 & 1 & 0 & 0 \\
gastropod (unidentified) & 39 & 43 & 24 & 0 & 1 \\
polycheate (unidentified) & 7 & 3 & 9 & 0 & 0 \\
polynoid polychaete & 6 & 0 & 2 & 0 & 0 \\
(unidentified) & & & & & \\
serpulid (unidentified) & 0 & 0 & 0 & 3 & 0 \\
cnidarian (unidentified) & 0 & 0 & 0 & 0 & 2 \\
isopod (unidentified) & 0 & 0 & 2 & 0 & 0 \\
\hline
\end{tabular}

\section{CONCLUSIONS}

Whereas conclusions drawn from the present study should be considered preliminary in light of the January 2006 eruption prematurely terminating our experiment, they are placed below in the perspective of the hypotheses specified at the beginning of the paper. (Hypothesis 1): The presence of extensive numbers of mussels within selected regions of the vent faunal assemblage inhibits the colonization and subsequent growth of vestimentiferan tubeworms through depletion of $\mathrm{H}_{2} \mathrm{~S}$ below critical levels. (Conclusion): The increase in $\mathrm{H}_{2} \mathrm{~S}$ concentrations after removal of mussels from our study site and the subsequent colonization and growth of vestimentiferan tubeworms is compatible with validity of this hypothesis. (Hypothesis 2): If mussels were to be removed and subsequently excluded from regions with elevated temperatures and $\mathrm{H}_{2} \mathrm{~S}$ concentrations within a mussel population at an active vent site along the East Pacific Rise, then the area will be colonized by numerous vent-endemic species, including $T$. jerichonana and $R$. pachyptila, that reportedly represent "early vent colonizers"; see Shank et al. (1998). (Conclusion): It seems that an area (with elevated temperatures and $\mathrm{H}_{2} \mathrm{~S}$ concentrations) from which mussels were removed and subsequently excluded was indeed colonized by numerous ventendemic species, including $T$. jerichonana and $R$. pachyptila. (Hypothesis 3): During later stages of succession, as $\mathrm{H}_{2} \mathrm{~S}$ levels are reduced by the overlying mussel population, the 
vestimentiferan Oasisia alvinae remains as the last ("climax") vestimentiferan in and among the mussel population. (Conclusion): If one assumes that $T$. jerichonana, two specimens of which were present on the recovered basalt blocks, was a very early colonizer that was subsequently "out-competed" by $R$. pachyptila, 66 specimens of which were present on the recovered blocks, then the presence of only three small $O$. alvinae on only one of the blocks (Block \#5, at which temperature and $\mathrm{H}_{2} \mathrm{~S}$ values were the highest) is consistent with this species being the last ("climax") vestimentiferan in and among the mussel population. (Hypothesis 4): Seismic events will alter the chemistry and temperatures of diffuse hydrothermal vent fluids within the region. (Conclusion): Whereas our results are indeed preliminary and nondefinitive, several correlations between seismicity, vent fluid temperatures, and the concentration of $\mathrm{H}_{2} \mathrm{~S}$ in vent fluids were present within the obtained data and suggest that seismic events may indeed alter the chemistry and temperatures of diffuse hydrothermal vent fluids within the region. (Hypothesis 5): Specific bacteria are repeatedly found in newly-established microbial filamentous communities from different diffuse flow vents within the general area of our study site along the EPR. (Conclusion): The reported occurrence of Halothiobacillus sp. as part of the filamentous microbial community on the block (Block \#5) in the center of the exclusion cage and on pieces of equipment left in nearby vent areas, as well as on natural substrates in adjacent vent fields, suggests that these microorganisms may serve as newly-formed biofilms associated with diffuse flows. These biofilms, in turn, might be an important factor controlling the settlement of larvae and subsequent colonization of vent metazoans. (Hypothesis 6): Mesophilic facultative and obligate autotrophic microorganisms are important components of the microbial assemblages in diffuse vent flows and associated thermal plumes. (Conclusion): The isolation of obligatively autotrophic Thiomicrospira spp. and facultatively autotrophic Halomonas spp. from $10^{-3}$ and $10^{-4}$ dilutions of the hydrothermal fluids at the Marker 119 site (and from even higher dilutions in fluids collected at other nearby vents in the region) clearly indicates that both these species are abundant (and likely relevant) constituents of the microbial communities that inhabit diffuse flow vents on the EPR.

\section{ACKNOWLEDGMENTS}

The authors thank the pilots of DSV Alvin and the crew of the $R / V$ Atlantis for their invaluable technical expertise and assistance. The authors are deeply indebted to the following individuals, without whose dedicated efforts, both on board the ship and in the laboratory, this interdisciplinary study would not have been possible: Kate Buckman, Walter Cho, Abigail Fusaro, Breea Govenar, Diane Poehls, Chris Janzen, Charoenkwan Kraiya, Jeffrey Tsang, Tim Waite, Delwayne Bohnenstiehl, Michael Hügler, Ronald Wong, Jasmine Ashraf, My Do, Adam Bohnert, Ileana Perez, and Ryan Lutz. Robert Weekly and Won-Young Kim are thanked for their help with processing the seismic data. We thank Tamar Barkay for many stimulating discussions concerning our results. Supported by NSF Grants OCE-9529819, ESI-0087679 (RAL), OCE-0327353 (RAL and CV), OCE-0327261, OCE-0451983 (TS), MCB-0456676, CHE-0221978 (CV), OCE-0326434 (GWL), and OCE-0327283 (MT), the Deep Ocean Exploration Institute at the Woods Hole Oceanographic Institution, and the New Jersey Agricultural Experiment Station at Rutgers University.

\section{LITERATURE CITED}

Antunes, A., W. Eder, P. Fareleira, H. Santos \& R. Huber. 2003. Salinisphaera shabanensis gen. nov., sp. nov., a novel, moderately halophilic bacterium from the brine-seawater interface of the Shaban Deep, Red Sea. Extremophiles 7:29-34.

Brendel, P. J. \& G. W. Luther, III. 1995. Development of a gold amalgam voltammetric microelectrode for the determination of dissolved $\mathrm{Fe}, \mathrm{Mn}, \mathrm{O}_{2}$ and $\mathrm{S}(-\mathrm{II})$ in porewaters of marine and freshwater sediments. Environ. Sci. Technol. 29:751-761.

Campbell, B. J., C. Jeanthon, J. E. Kostka, G. W. Luther, III \& S. C. Cary. 2001. Growth and phylogenetic properties of novel epsilon proteobacteria enriched from Alvinella pompejana and Deep-sea hydrothermal vents. Appl. Environ. Microbiol. 67:4566-4572.

Cary, S. C., M. T. Cottrell, J. L. Stein, F. Camacho \& D. Desbruyeres. 1997. Molecular identification and localization of filamentous symbiotic bacteria associated with the hydrothermal vent annelid Alvinella pompejana. Appl. Environ. Microbiol. 63:1124-1130.

Comtet, T., D. Jollivet, A. Khripounoff \& M. Segonzac. 2000. Molecular and morphological identification of settlement-stage vent mussel larvae, Bathymodiolus azoricus (Bivalvia: Mytilidae), preserved in situ at active vent fields on the Mid-Atlantic Ridge. Limnol. Oceanogr. 45:1655-1661.

Corre, E., A.-L. Reysenbach \& D. Prieur. 2001. ع-Proteobacterial diversity from a deep-sea hydrothermal vent on the Mid-Atlantic Ridge. FEMS Microbiol. Lett. 205:329-335.

Dowling, T. E., C. Moritz, J. D. Palmer \& L. H. Rieseberg. 1996. Nucleic acids III: analysis of fragments and restriction sites. In D. M. Hillis, C. Moritz \& B. K. Mable, editors. Molecular Systematics, 2nd ed. Sunderland, Massachusetts: Sinauer Associates. pp. 249-320.
Durand, P., A.-L. Reysenbach, D. Prieur \& N. R. Pace. 1993. Isolation and characterization of Thiobacillus hydrothermalis sp. nov., a mesophilic obligately chemolithotrophic bacterium isolated from a deep-sea hydrothermal vent in the Fiji Basin. Arch. Microbiol. 159:39-44.

Fornari, D. J., T. M. Shank, K. L. Von Damm, T. K. P. Gregg, M. D. Lilley, G. Levai, A. Bray, R. Haymon, M. Perfit \& R. A. Lutz. 1998. Time series temperature measurements at high temperature hydrothermal vents, East Pacific Rise $9^{\circ} 49^{\prime}-51^{\prime} \mathrm{N}$ : Monitoring a crustal cracking event. Geophys. Res. Lett. 160:419-431.

France, S. C. \& T. D. Kocher. 1996. DNA sequencing of formalin-fixed crustaceans from archival research collections. Mol. Mar. Biol. Biotechnol. 5:304-313.

Gundersen, J. K., B. B. Jorgensen, E. Larsen \& H. W. Jannasch. 1992. Mats of giant sulphur bacteria on deep-sea sediments due to fluctuating hydrothermal flow. Nature 360:454-456.

Haymon, R. M., D. J. Fornari, M. H. Edwards, S. Carbotte, D. Wright \& K. C. Macdonald. 1991a. Hydrothermal vent distribution along the East Pacific Rise crest $\left(9^{\circ} 09^{\prime}-54^{\prime} \mathrm{N}\right)$ and its relationship to magmatic and tectonic processes on fast-spreading mid-ocean ridges. Earth Planet. Sci. Lett. 104:513-534.

Haymon, R. M., D. Fornari, K. Von Damm, J. Edmond, M. Lilley, M. Perfit, W. S. Shanks, III, J. Grebmeier, R. Lutz, S. Carbotte, D. Wright, M. Smith, E. McLaughlin, N. Beedle, J. Seewald, D. Reudelhuber, E. Olson \& F. Johnson. 1991b. East Pacific Rise erupts north of Leg 142 drillsite! JOI-USSAC Newsletter 4:4-12.

Haymon, R. M., D. J. Fornari, K. Von Damm, J. Edmond, M. Lilley, M. Perfit, W. S. Shanks, III, J. Grebmeier, R. Lutz, S. Carbotte, 
D. Wright, M. Smith, E. McLaughlin, N. Beedle, J. Seewald, D. Reudelhuber, E. Olson \& F. Johnson. 1991c. Eruption of the EPR crest at $9^{\circ} 45^{\prime}-52^{\prime} \mathrm{N}$ since later 1989 and its effects on hydrothermal venting: Results of the ADVENTURE Program, an ODP site survey with Alvin. Eos 72:480.

Haymon, R. M., S. Carbotte, D. Wright, N. Beedle, F. Johnson, D. Fornari, K. Von Damm, J. Grebmeier, M. Lilley, E. Mclaughlin, E. Olson, J. Edmond, M. Perfit, M. Smith, W. C. Shanks, R. Lutz, J. Seewald \& D. Reudelhuber. 1991d. Active eruption seen on East Pacific Rise. Eos 72:505-507.

Haymon, R. H., D. J. Fornari, K. L. Von Damm, M. D. Lilley, M. R. Perfit, J. M. Edmond, W. C. Shanks, III, R. A. Lutz, J. M. Grebmeier, S. Carbotte, D. Wright, E. McLaughlin, M. Smith, N. Beedle \& E. Olson. 1993. Volcanic eruption of the Mid-ocean Ridge along the East Pacific Rise Crest at $9^{\circ} 45^{\prime}-52^{\prime} \mathrm{N}$ : Direct submersible observation of seafloor phenomena associated with an Eruption Event in April, 1991. Earth Planet. Sci. Lett. 119:85-101.

Hessler, R. R., W. M. Smithey, M. A. Boudrias, C. H. Keller, R. A. Lutz \& J. J. Childress. 1988. Temporal change in megafauna at the Rose Garden hydrothermal vent (Galapagos Rift; eastern tropical Pacific). Deep-Sea Res. 35:1681-1709.

Huber, J. A., D. A. Butterfield \& J. A. Baross. 2003. Bacterial diversity in a subseafloor habitat following a deep-sea volcanic eruption. FEMS Microbiol. Ecol. 43:393.

Jannasch, H. W., C. O. Wirsen, D. C. Nelson \& L. A. Robertson. 1985. Thiomicrospira crunogena sp. nov., a colorless sulfur-oxidizing bacterium from a deep-sea hydrothermal vent. Int. J. Syst. Bacteriol. $35: 422-424$.

Jannasch, H. W., D. C. Nelson \& C. O. Wirsen. 1989. Massive natural occurrence of unusually large bacteria (Beggiatoa sp.) at a hydrothermal deep-sea vent site. Nature 324:834-836.

Johnson, K. S., J. J. Childress, R. R. Hessler, C. M. Sakamoto-Arnold \& C. L. Beehler. 1988a. Chemical and biological interactions in the Rose Garden hydrothermal vent field, Galapagos Spreading Center. Deep-Sea Res. 35:1723-1744.

Johnson, K. S., J. J. Childress \& C. L. Beehler. 1988b. Short-term temperature variability in the Rose Garden hydrothermal vent fields: An unstable deep-sea environment. Deep-Sea Res. 35:17111722.

Johnson, K. S., J. J. Childress, C. L. Beehler \& C. M. Sakamoto. 1994. Biogeochemistry of hydrothermal vent mussel communities: the deep-sea analogue to the intertidal zone. Deep-Sea Res. 41:9931011.

Kaye, J. Z. \& J. A. Baross. 2000. High incidence of halotolerant bacteria in Pacific hydrothermal- vent and pelagic environments. FEMS Microbiol. Ecol. 32:249-260.

Kaye, J. Z., M. C. Marquez, A. Ventosa \& J. A. Baross. 2004. Halomonas neptunia sp. nov., Halomonas sulfidaeris sp. nov., Halomonas axialensis sp. nov. and Halomonas hydrothermalis sp. nov.: halophilic bacteria isolated from deep-sea hydrothermal-vent environments. Int. J. Syst. Evol. Microbiol. 54:499-511.

Klein, F. W. 2002. User's Guide to HYPOINVERSE2000, a Fortran program to solve for earthquake locations and magnitudes. US geological survey, Open file report 02-172, $123 \mathrm{pp}$.

Longnecker, K. \& A. L. Reysenbach. 2001. Expansion of the geographic distribution of a novel lineage of $\varepsilon$-Proteobacteria to a hydrothermal vent site on the Southern East Pacific Rise. FEMS Microbiol. Ecol. 35:287-293.

Lopez-Garcia, P., F. Gaill \& D. Moreira. 2002. Wide bacterial diversity associated with tubes of the vent worm Riftia pachyptila. Environ. Microbiol. 4:204-215.

Luther, G. W., III, B. T. Glazer, L. Hohman, J. I. Popp, M. Taillefert, T. F. Rozan, P. J. Brendel, S. M. Theberge \& D. B. Nuzzio. 2001a. Sulfur speciation monitored in situ with solid state gold amalgam voltammetric microelectrodes: polysulfides as a special case in sediments, microbial mats and hydrothermal vent waters. J. Environ. Monit. 3:61-66.
Luther, G. W., III, T. F. Rozan, M. Taillefert, D. B. Nuzzio, C. Di Meo, T. M. Shank, R. A. Lutz \& S. C. Cary. 2001b. Chemical speciation drives hydrothermal vent ecology. Nature 410:813-816.

Luther, G. W., III, A. Bono, M. Taillefert \& S. C. Cary. 2002. A continuous flow electrochemical cell for analysis of chemical species and ions at high pressure: laboratory, shipboard and hydrothermal vent results. In: M. Taillefert, T. Rozan, editors. Environmental electrochemistry: analyses of trace element biogeochemistry, American Chemical Society Symposium Series, American Chemical Society, Washington, D.C. 811. pp. 54-73.

Lutz, R. A. \& R. M. Haymon. 1994. Rebirth of a deep-sea vent. Natl. Geogr. Mag. 186:114-126.

Lutz, R. A., T. M. Shank, D. J. Fornari, R. M. Haymon, M. D. Lilley, K. L. Von Damm \& D. Desbruyères. 1994. Rapid growth at deepsea vents. Nature 371:663-664.

Lutz, R. A., T. M. Shank \& R. Evans. 2001. Life after death in the deep sea. Am. Sci. 89(5):422-431.

Micheli, F., C. H. Peterson, L. S. Mullineaux, C. R. Fisher, S. W. Mills, G. Sancho, G. A. Johnson \& H. S. Lenihan. 2002. Predation structures communities at deep-sea hydrothermal vents. Ecol. Monogr. 72:365-382.

Moyer, C. L., F. C. Dobbs \& D. M. Karl. 1995. Phylogenetic diversity of the bacterial community from a microbial mat at an active, hydrothermal vent system, Loihi Seamount, Hawaii. Appl. Environ. Microbiol. 61:1555-1562.

Mullineaux, L., C. R. Fisher, C. H. Peterson \& S. W. Schaeffer. 2000. Tubeworm succession at hydrothermal vents: use of biogenic cues to reduce habitat selection error? Oecologia 123:275-284.

Nelson, D. C., C. O. Wirsen \& H. W. Jannasch. 1989. Characterization of large, autotrophic Beggiatoa spp. abundant at hydrothermal vents of the Guaymas Basin. Appl. Environ. Microbiol. 55:2909-2917.

Nelson, D., R. M. Haymon, M. Lilley \& R. Lutz. 1991. Rapid growth of unusual hydrothermal bacteria observed at new vents during the ADVENTURE Dive Program to the EPR Crest at $9^{\circ} 45^{\prime}-52^{\prime}$ N. Eos 72:481.

Nuzzio, D. B., M. Taillefert, S. C. Cary, A. L. Reysenbach \& G. W. Luther, II. 2002. In situ voltammetry at hydrothermal vents. In: M. Taillefert \& T. Rozan, editors. Environmental electrochemistry: analyses of trace element biogeochemistry, American Chemical Society Symposium Series, American Chemical Society: Washington, DC, 811. pp. 40-53.

Rubin, K. H. \& J. D. MacDougall. 1991. Fine chronology of recent midocean ridge eruptions on the southern $\mathrm{DF}$ and $9^{\circ} \mathrm{N}$ EPR from ${ }^{226} \mathrm{Ra}^{230}{ }^{23 h}-{ }^{238} \mathrm{U}$ and ${ }^{210} \mathrm{Po}^{210} \mathrm{~Pb}$ disequilibrium. Eos $72: 231$.

Rubin, K. H., J. D. Macdougall \& M. R. Perfit. $1994 .{ }^{210} \mathrm{Po}-{ }^{210} \mathrm{~Pb}$ dating of recent volcanic eruptions on the sea floor. Nature 368:841-844.

Ruby, E. G., C. O. Wirsen \& H. W. Jannasch. 1981. Chemolithotrophic sulfur-oxidizing bacteria from the Galapagos Rift hydrothermal vents. Appl. Environ. Microbiol. 42:317-324.

Shank, T. M. \& K. M. Halanych. 2007. Toward a mechanistic understanding of larval dispersal: insights from genomic fingerprinting of the deep-sea hydrothermal vent tubeworm Riftia pachyptila. Mar. Ecol. 28:25-35.

Shank, T. M., D. J. Fornari, K. Von Damm, M. Lilley, C. L. Van Dover, G. Levai \& R. A. Lutz. 1995. Dynamic fluctuations and cyclic periodicities of Low-T hydrothermal venting: Time-lapse Multi-probe temperature measurements and video imaging at $9^{\circ} 49.8^{\prime} \mathrm{N}$ on the East Pacific Rise Crest. Results from Dec. 1993 to October 1995. Eos 76:701.

Shank, T. M., D. J. Fornari \& R. A. Lutz. 1997. Periodicities and variability of high and low- temperature hydrothermal venting along the Biotransect (9 500N) on the East Pacific Rise: Three years of continuous synchronous temperature monitoring. Eos 78:739.

Shank, T. M., D. J. Fornari, K. L. Von Damm, M. D. Lilley, R. M. Haymon \& R. A. Lutz. 1998. Temporal and spatial patterns of biological community development at nascent deep-sea hydrothermal vents along the East Pacific Rise. Deep-Sea Res. 45:465-515. 
Scheirer, D. S., T. M. Shank \& D. J. Fornari. 2006. Temperature variations at diffuse and focused flow hydrothermal vent sites along the northern East Pacific Rise. Geochem. Geophys. Geosys. 7:1-23.

Shiozawa, D. K., J. Kudo, R. P. Evans, S. R. Woodward \& R. N. Williams. 1992. DNA extraction from preserved trout tissues. Great Basin Nat. 52:29-34.

Sorokin, D. Y., T. P. Tourova, E. M. Spiridonova, F. A. Rainey \& G. Muyzer. 2005. Thioclava pacifica gen. nov., sp. nov., a novel facultatively autotrophic, marine, sulfur-oxidizing bacterium from a near-shore sulfidic hydrothermal area. Int. J. Syst. Evol. Microbiol. 55:1069-1075.

Taylor, C. D. \& C. O. Wirsen. 1999. Rapid microbial production of filamentous sulfur mats at hydrothermal vents. Appl. Environ. Microbiol. 65:2253-2255.

Thiebaut, E., X. Huther, B. Sillito, D. Jollivet \& F. Gaill. 2002. Spatial and temporal variations of recruitment in the tube worm Riftia pachyptila on the East Pacific Rise $\left(9^{\circ} 50^{\prime} \mathrm{N}\right.$ and $\left.13^{\circ} \mathrm{N}\right)$. Mar. Ecol. Prog. Ser. 234:147-157.

Tolstoy, M., J. P. Cowen, E. T. Baker, D. J. Fornari, K. H. Rubin, T. M. Shank, F. Waldhauser, D. R. Bohnenstiehl, D. W. Forsyth, R. C.
Holmes, B. Love, M. R. Perfit, R. T. Weekly, S. A. Soule \& B. Glazer. 2006. A sea-floor spreading event captured by seismometers. Science 314:1920-1922.

Von Damm, K. L. 1991. Preliminary chemistry of hydrothermal vent fluids from $9-10^{\circ} \mathrm{N}$ East Pacific Rise. Eos 72:480.

Von Damm, K. L., S. E. Oosting \& L. G. Buttermore. 1994. Chemical evolution of diffuse hydrothermal fluids from $9^{\circ} 49-50^{\prime} \mathrm{N}$ EPR: The BIOGEOTRANSECT Area. Eos 75:601.

Vos, P., R. Hogers, M. Bleeker, M. Reijans, T. van de Lee, M. Hornes, A. Frifiters, J. Pot, J. Peleman, M. Kuiper \& M. Xabeau. 1995. AFLP: A new technique for DNA fingerprinting. Nucleic Acids Res. 23:4407-4414.

Waldhauser, F. \& W. L. Ellsworth. 2000. A double-difference earthquake location algorithm: Method and application to the Northern Hayward Fault, California. Bull. Seismol. Soc. America 90:13531368.

Wirsen, C. O., T. Brinkhoff, J. Kuever, G. Muyzer, S. Molyneaux \& H. W. Jannasch. 1998. Comparison of a new Thiomicrospira strain from the mid-atlantic ridge with known hydrothermal vent isolates. Appl. Environ. Microbiol. 64:4057-4059. 